\title{
ProF. SCHLEGEL'S ZOOGENAAMDE KRITIEK VAN HET JAPANSCH-NEDERLANDSCH EN JAPANSCH-ENGELSCH WOORDENBOEK DEEL III,
}

in de Bijdragen tot de taal-, land-en volkenkunde van Nerlerlandsch-Indië, $5^{\mathrm{e}}$ volgreeks, $8^{\mathrm{e}}$ deel, $1^{\mathrm{e}}$ aflev. 1893 , bl. 33 en volgg., beantwoord

DOOR

Mr. L. SERRURIER.

Onder bovenstaanden titel heb ik een vlugsehrift in het licht gegeven, om mij te verdedigen tegen de aanvallen, door den heer Schlegel in de vorige aflevering van dit tijdschrift tegen mij gericht.

Ik heb daarin niet maar bewoeerd, doch bewezen, dat zijue taalkundige aanmerkingen allen grond missen en zonder onderscheid berusten op zijne volkomen onbekendheid met de japansche taal. Ja, waar de heer Schlegel mij op zijn eigen gebied aanvalt, daar heb ik moeten constateeren, dat het verwijt van slordigheid, tot mij gericht, op hemzelven terugvalt, angezien hij verzuimd heeft na te gaan, of de in Japan gebruikelijke, doch hem onbekende beteekenis van chineesche karakters, ook oudtijds in China aan die karakters gehecht is geweest. Hij had dit in zijn Kang- $h i$ kunnen vinden.

Ik zal mijne taalkundige argumenten hier niet herhalen, en verwijs daarvoor naar mijn vlugschrift, waarvan ik, zoolang de voorraad strekt, gaarne een exemplaar op aanvrage aan belangstellenden zal toezenden. Maar ik wensch hier nog met een enkel woord te releveeren, dat ik met verontwaardiging van mij werp de insinuatie, van den verdienstelijken arbeid van wijlen mijnen hooggeschatten leermeester tot den mijnen te hebben willen maken of te verkleinen. Ieder deel van het woordenboek ontvangt een eigen titel, terwijl aan het einde van het geheele werk een passende algemeene titel zal worden vastgesteld. Voor dit deel heb ik er een gekozen, waaruit ten duidelijkste blijkt, dat slechts enkele losse aanteekeningen van Hoftmann daarvoor zijn nagelaten en dus de verantwoordelijkheid voor dezen arbeid nagenoeg uitsluitend voor mijne rekening komt. De heer Schlegel 
kan geen onwetendheid hiervan voorwenden, zooals ik in eene noot aan den voet der eerste bladzijde heb aangetoond.

- Wat den tragen gang der publicatie betreft, zoo ben ik van meening, dat ik daarvan aan niemand anders verantwoording schuldig ben dan aan de Regeering, die mij het werk heeft opgedragen.

Wanneer een wetenschappelijke arbeid in eigen land het licht ziet, wanneer die op last fler eigen regeering wordt ondernomen; wanneer daaraan de naam van den eigen leermeester verbonden is, wiens nagedachtenis men zegt in eere te houden, dan moge dit al niet terughouden van eene, zoo noodig gestrenge beoordeeling; maar dan behoort er eene verdubbelde omzichtigheid te worden in acht genomen, om niet lichtvaardig dien arbeid, vooral tegenover het buitenland, te verkleinen. Prof. Schlegel heeft dit geheel uit het oog, verloren. Niet tevreden met zijne onbevoegde kritiek in het tijdschrift van het Institunt onder de aandacht te brengen van hen, die meestal niet in staat zijn zijne argumenten na te gaan, herhaalt hij die in het engelsch in zijn eigen tijdschrift $T_{o u n g}^{c} P a o$ ten dienste van de vakgeleerden. Roekeloos stapelt hịj de eene onjuistheid op de andere, en doet dit op een toon, die aan andere beweegredenen doet denken, dan bevordering van de belangen der wetenschap.

Er zijn zonder twijfel fouten in mijn arbeid, en ik mak de woorlen van prof. Schlegel in de voorrede van zijn nederlandschchine sch woordenboek tot de mijne: "dat het niet volmakt is, zal een ieder, die noit een woordenboek vervaardigd heeft, gemakkelijk begrịjpen;" doch om die fouten te vinden, behoort men niet, zooals de heer Schlegel, uitsluitend sinoloog te ziju.

Leiden, 20 Januari 1893.

Serrurifr. 